\title{
JUS DOMICILE: IN PURSUIT OF A CITIZENSHIP OF EQUALITY AND SOCIAL JUSTICE
}

\author{
HARALD BAUDER
}

\begin{abstract}
Although foreign workers contribute to the economy and society, their lack of citizenship renders them unequal, vulnerable and exploitable. In this article, I suggest that the citizenship principle of jus domicile can address this aspect of inequality and exploitation experienced by migrant labour. In addition, I argue that the jus domicile principle should be combined with open borders. In making this argument, I draw on a dialectical methodology and a diverse literature on social justice and liberal political theory. The model I am developing is not necessarily for immediate policy implementation but rather presents a vision for a future of free mobility and settlement.
\end{abstract}

Keywords: Citizenship, distinction, jus domicile, liberal theory, open borders, social justice

\section{Introduction}

Foreign migrant workers are an increasingly important labour force for industrialized economies. Although foreign workers contribute to the economy and society, they are denied equality and remain politically excluded. Lacking the rights and entitlements associated with citizenship, these migrants are not only unequal human beings but they are also vulnerable and exploitable workers. Citizenship is a key attribute that distinguishes foreign migrant labour and workers with precarious status from citizens.

In this article, I build on existing empirical and theoretical research to explore the conditions that would be necessary for labour migration to occur in an equitable and socially just manner. In this exploration, I bring together various bodies of literature, including a social theory perspective of distinction and

Journal of International Political Theory, 8(1-2) 2012, 184-196

DOI: 10.3366/jipt.2012.0038

(C) Edinburgh University Press 2012

www.eupjournals.com/jipt 
reproduction, a discussion of the jus domicile principle of citizenship and an ongoing debate of open borders. In this way, I follow recent calls for multidisciplinarity and conceptual pluralism in the context of migration research, and social and political theory (van den Anker 2010).

This article envisions a normative model for labour mobility and community membership. In particular, I examine if the principle of jus domicile 'could ... be an alternative premise for citizenship' (Kostakopoulou 2008: 112) and solve some of the problems that the currently dominant jus soli and jus sanguinis principles of citizenship have created. Researchers have correctly noted the contradictions and shortcomings of territorial citizenship principles like jus domicile (see Bosniak 2007). I seek to address these contradictions and shortcomings by including the notion of open borders into the discussion. Given contemporary political circumstances and economic structures, my vision of labour mobility and community membership may not necessarily be ready for immediate implementation. Yet, this vision can guide future policies that return to the 'historical norm in human society' of free mobility and settlement (Juss 2004: 289).

My methodology involves a dialectical process, whereby I explore contradictions that arise from examining migration and citizenship from different perspectives. These perspectives include a social justice perspective conceiving of citizenship and borders as 'technologies of power' (Walters 2006: 187), and a liberal political theory perspective that emphasizes universality and equality. These perspectives may at some level be incompatible with each other (see Brown 1992); yet, their contradictions resolve - or at least diminish-under the condition of jus domicile citizenship and free mobility, for which I am arguing.

My critique does not deny the concept of citizenship. On the one hand, I am critical of certain principles and practices of citizenship that enshrine privilege and facilitate its reproduction. On the other hand, I recognize the value citizenship has as a mechanism to provide rights and guarantee the equality among human beings. The latter, I argue, can be achieved through the jus domicile principle.

In the sections below, I first discuss how citizenship serves as a mechanism of distinction and exclusion. Second, I discuss how the jus domicile principle of citizenship addresses the injustice and inequality produced by this mechanism. Third, I expand on the open borders argument in an effort to resolve emerging contradictions arising from jus domicile. I conclude by highlighting unresolved issues, discussing newly arising contradictions and making suggestions for further debate.

\section{Citizenship as Mechanism of Distinction}

Citizenship connotes inclusion and belonging in a political community, the possession of political, social and economic rights, and the promise of equality between fellow citizens and social groups (Isin and Turner 2002). The flipside 
of citizenship, however, is that non-citizens are excluded from membership in the community and often denied the right to equal treatment. From a liberal political theory perspective, it is problematic to treat people unequally based on characteristics, such as citizenship, which individuals usually acquire at birth. Similarly, from a social justice viewpoint, citizenship lies at the heart of the unfair distribution of social, political and economic benefits and responsibilities and the disproportionate exploitation of some workers. This flipside of citizenship is particularly relevant in the context of migrant labour. Non-citizen workers are often denied basic economic rights, temporary foreign workers may not choose their occupation or employer, and non-status immigrants lack the most basic protection of the state, which citizens (and some migrants) take for granted. The lack of citizenship is an important condition that renders many foreign workers vulnerable and exploitable. Although lack of citizenship is neither always nor necessarily associated with exclusion and exploitation, it is a condition that often leads to these outcomes, as empirical work has shown (Bauder 2006; Sharma 2006).

Expanding on the work of Pierre Bourdieu (1984), citizenship can be theorized as a mechanism of social distinction and reproduction. According to Bourdieu, social groups use the resources at their disposal strategically to distinguish themselves from other groups. Bourdieu conceptualized these resources as forms of 'capital' because they enable people who possessed them to gain an advantage over those who lack them. Accordingly, social capital (i.e. social connections and group membership), cultural capital (i.e. symbolic representations of status) and economic capital (i.e. monetary resources) define different mechanisms of distinction and reproduction (Bourdieu 1986). In the context of migration, citizenship embodies a legal form capital: the legal privileges associated with citizenship define a set of resources that permit citizens to distinguish themselves from non-citizens (Bauder 2008).

In the context of global labour-market inequalities, citizenship-i.e. usually of the country in which citizens reside - is an important variable that shapes wage structures, labour standards and conditions of employment. A worker in, say, Indonesia, typically receives less pay for the equal task than a worker in the USA, even after accounting for education, other forms of social and cultural capital, as well as technology and unequal exchange (van Parijs 1992). The differential treatment of workers based on the country of their citizenship has created an 'international segmentation of labour' (Bauder 2006; Samers 2010), whereby workers in 'less industrialized' ${ }^{1}$ countries serve subservient roles in the global economy relative to workers in 'industrialized' countries. When workers from countries with lower wages and labour standards migrate to countries with higher wages and labour standards, they often continue to serve as subservient labour; their lack of citizenship segments them into lower labour market positions. Citizenship is a key mechanism that preserves the international segmentation of labour within industrialized countries (Bauder 2006). 
The character of citizenship as a form of capital in the Bourdieuen sense is validated by the fact that citizenship is strategically enacted by citizens and their political representatives to achieve the aims of distinction and reproduction. Canada's temporary foreign workers program exemplifies this strategic enactment of citizenship. This country's immigration system carefully separates highly-skilled workers, who are invited to permanently immigrate to Canada via a points system and are eligible for Canadian citizenship after a few years, from low-skill workers, who are disproportionately relegated to the temporary foreign workers program. Temporary foreign workers do not possess equal rights to permanent residents or citizens. For example, they cannot freely choose an occupation or freely switch employers, and they have to leave both employment and residence when their visas expire. The strategic production of this vulnerable labour force without citizenship is demonstrated by the fact that the Canadian government has increased the number of temporary foreign-worker visas in recent years to exceed the number of permanent immigrants to Canada (Austin and Bauder 2010; Sharma 2006).

The point is that current citizenship practices enforce and reproduce systems of domination and subordination. From a social justice viewpoint, these practices are unacceptable because they contribute to the segmentation and disproportionate exploitation of some workers. Similarly, from a liberal political theory viewpoint, these practices cannot be tolerated because they enable one group of people to dominate over another. The question that follows from the above discussion is this: how should citizenship and citizenship practices be reconfigured to counter the domination and disproportionate exploitation of migrant workers? Below, I explore the suitability of the jus domicile citizenship principle to address this question.

\section{Jus Domicile}

Different principles exist through which people acquire formal citizenship and thus become equal members of a political community. The principle of jus sanguinis (right of blood) refers to citizenship based on ancestry; parents pass their citizenship on to their offspring at birth. The principle of jus soli (right of the soil) refers to citizenship based on place of birth; persons acquire citizenship of the political territory in which they are born. Although contemporary nation states usually favour one principle over the other, they typically employ a mix of both principles to grant citizenship to their subjects. A third principle of citizenship is known as jus domicile (right of residence), referring to citizenship based on place of residence. Jus domicile citizenship is neither necessarily granted at birth nor permanently ${ }^{2}$ but rather based on the de facto belonging in a territory and the associated community. According to Dora Kostakopoulou's (2008: 115) description of the jus domicile principle, 'the relevant and important 
factor for citizenship acquisition is not place per se, but the connections and bonds of association that one establishes by living and participating in the life and work of the community'. ${ }^{3}$ My concern in this paper is not to offer any details on how to operationalize jus domicile. Rather, my aim is to construct a theoretical and practical case in support of the principle of jus domicile.

From the perspective of liberal political theory, jus soli and jus sanguinis principles are problematic because citizenship is not freely chosen but ascribed at birth (Brubaker 1992). Thus, these principles reproduce birth privilege; they grant citizenship based on the 'accident of birth', not unlike feudal privileges that were once passed on from one generation to the next. Jus domicile addresses this problem by granting people citizenship based on the community to which they actually belong - whether they were born into this community or chose to join it through migration (Bauböck 1994). Furthermore, by including migrant residents, the jus domicile principle of citizenship is consistent with the preconditions of liberal democracy: 'democratic decision making and the flourishing of a political community require the involvement of all the community-not simply of a segment of it' (Kostakopoulou 2008: 126). The jus domicile principle ensures that the means for democratic political participation are bestowed on all de facto members of the community.

Likewise, from a social justice viewpoint, jus sanguinis and jus soli principles are problematic because they permit maintaining distinctions among people who are residing in the same place but may contribute equally to the community. In fact, members of the community who are excluded from citizenship often make greater economic contributions than citizens. Étiene Balibar (2000: 42) refers to undocumented migrant workers as 'modern proletarians' who make sacrifices for society which are greatly disproportionate to the benefits the community returns to them. Pierre Bourdieu (2002: 40) has made a similar point, calling the sans papiers a 'global reserve army of labor' relegated to serve privileged segments of society. At the core of these injustices is the dispossession of the rights and entitlements reserved for citizens.

The jus domicile citizenship principle would tackle this social injustice. This principle distinguishes between people who are present in a territorial community and people who are absent from it. All de facto members within the community are included, obtain citizenship and need to receive equal treatment. The jus domicile principle would thus eliminate formal citizenship as a mechanism of domination based on birth privilege and labour segmentation within a territorial community.

Similarities exist between jus domicile citizenship and current political practices. International law grants most migrants a set of basic rights even when they do not possess formal citizenship of the country in which they reside. Furthermore, migrants often acquire additional rights and entitlements once they locate in a community and make social and economic contributions to this community. Yasemin Nuhoğlu Soysal (1994: 12) called this accumulation 
of rights and entitlements postnational citizenship. She claims that formal citizenship in a nation state is no longer the main determinant of individual rights and privileges'. Rather, personhood enshrines access to rights. Her research showed how non-citizen migrants in Europe acquire social, economic and political rights through residency, making contributions to social security and employment insurances, and other forms participation. Yet, in the examples which Soysal cites, such as Turks in Germany, migrant were first selected through a guest workers program and had to undergo a series of probationary and stepwise residency and employment hurdles before they accrued additional rights. Elsewhere, such as in the USA, migrants also tend to receive rights gradually, in the form of an 'incremental process from less to more' (Bosniak 2007: 291). During this incremental process, migrants are often subjected to arbitrary measures and self-serving objectives of the state and its citizens, including the aim to provide exploitable labour to the national economy.

In traditional immigration countries, such as Australia, Canada or the USA, immigration and naturalization practices arguably emulate the jus domicile principle of citizenship. Immigrants can apply for citizenship when they meet certain conditions, typically related to the length of permanent residency, possession of basic knowledge of the state's history and governance, and the demonstration (and expression) of their loyalty to the state. Some countries also offer pathways from temporary to permanent residency. In Canada, for example, the Live-in-Caregiver Program and the Canadian Experience Class mimic the jus domicile principle of citizenship by offering permanent residency with the future prospect of citizenship to temporary workers who meet certain conditions (Austin and Bauder 2012). In non-traditional immigration countries, naturalization is also possible based on residency and other criteria, although in these countries naturalization tends to be less formally regulated and give state bureaucracies greater discretion than in traditional immigration countries. Under the policies pursued by both traditional and non-traditional immigration countries, migrants are first carefully selected to enter a country; thereafter they are placed under a period of probation when they are vulnerable and possess an intermediate-level status; only then are they eligible for naturalization.

Postnational rights and naturalization may reward workers for the contributions they are making to their community. However, the problem with both naturalization and the accumulation of postnational rights is that citizenship is not articulated as a 'right' that all persons who reside in the community possess. Simply arguing that migrants need to be treated with respect is not enough. Even Michael Walzer (1983: 52-61) - who argued against free territorial admission of people (a point I will challenge later) - conceded that resident aliens and 'guest workers' must be included in the political decisions making process as a matter of political justice. Anything else would amount to tyranny.

Moreover, the conferring of citizenship through naturalization and the extension of postnational rights occurs on the basis of carefully calibrated 
practices of selection and exclusion. Under these practices, non-status immigrants remain excluded from formal citizenship (unless they are granted an amnesty or permission to stay by executive order). Even 'regular' migrants become eligible for naturalization or can acquire postnational rights only after immigration and visa policies deemed them worthy of entry into the territory. As these examples illustrate, contemporary practices that emulate the jus domicile citizenship principle remain subject to state arbitrariness.

\section{Open Borders and the Right to Stay}

To realize the promises of social justice and equality associated with the jus domicile principle of citizenship requires a discussion of how a person can become eligible for citizenship in the first place. Given the above considerations, persons are only eligible after they have entered and settled in a territory. If they are prevented from entry or settlement, then questions of human inequality and social injustice arise again (see Bauder 2003; Carens 1987; Hayter 2000). 'Citizenship based on domicile puts emphasis on the bonds of association that individuals establish as members of a society. As such it is consonant with human mobility and peoples' rights to choose their civic and political home' (Kostakopoulou 2008: 119). Through the right to choose a home, the discussion of the jus domicile principle of citizenship relates to the ongoing debate of open borders. $^{4}$

Although open borders and jus domicile relate to different theoretical principles - the former to universal rights and mobility, the latter to democracy and membership - they are compatible with each other (Carens 2010: 36-7). In fact, they necessitate each other, I argue, at the practical level: from a liberal political theory point of argument, the jus domicile citizenship principle under conditions of restricted border mobility would only reproduce the birth-right of people who happen to be born in a territory and then decide who can enter this territory and thus qualify for membership (see Cole 2000). From a social justice perspective, restricting mobility is a way to deny workers the protective rights they would gain if they entered the territory and assumed jus domicile citizenship. Transnational corporations, for example, already circumvent a labour force endowed with rights by offshoring operations and exploit workers who are locked into territories abroad. Without open borders, the jus domicile principle of citizenship fails to achieve its promise of equality and social justice.

Contemporary migration policies and mobility practices, however, are highly restrictive and selective. They prevent many persons from entering, let alone working or settling in a territory, while they permit other migrants to work only on a temporary basis. In fact, temporary migration programs are often designed for the very purpose to prevent migrants from accumulating postnational rights or becoming citizens. For example, Canada's current temporary foreign workers 
program restricts work permits to such short periods and rigid employment conditions that foreign workers acquire neither extended economic, social and political postnational rights nor the right to stay in Canada. Although these workers are making important contributions to Canadian society and economy, they are denied equal membership in the national community.

From a liberal political theory perspective, this practice of excluding migrants deemed 'temporary' from the possibility to accrue rights to permanent residency while granting these rights to other migrants represents arbitrariness on the side of the state. Similarly, from a social justice viewpoint, this practice permits the exploitation of a segment of workers who is rendered vulnerable through the denial of the right to stay and the associated possibility to accumulate economic, social and political rights; it enables the international segmentation of labour within a country based on (the lack of) citizenship. If citizenship based on the jus domicile principle is not combined with equal and fair entry practices, then it can neither prevent the arbitrary treatment of migrants by the state nor the injustice and exploitation experienced by migrants who are denied permanent residency and rendered ineligible for citizenship.

To ensure that the principle of jus domicile addresses the problems of inequality and social injustice and is extended to all residents and members of the community, two conditions must be met: First, migrants who are de facto members of a community must possess the right to stay. This right must apply to all migrants who are making economic, civic and other worthy contributions to the community, including temporary workers and migrants with precarious status. Only when these members are no longer threatened with the expulsion from their community and are instead offered jus domicile citizenship, can they experience equality and social justice.

The second condition is that mobility must be a right. The right to enter a state's territory resonates with the open border argument. Joseph Carens (1987) was one of the first liberal theorists to develop this open border argument. Phillip Cole (2000) expanded upon it, explaining that mobility constraints violate overarching liberal principles, including the principle of universal human equality. Counter arguments are either unconvincing from universalist viewpoints or they produce a 'liberal paradox' of contradictions and tensions between universalist and other (e.g. communitarian) branches of liberal theory (Verlinden 2010): while the Hobbesian state may have a right to defend itself, the vast majority of migrants do not threaten but seek to contribute to the community; although a community may have a right to define its own collective identity (Walzer 1983), the identity of most contemporary political entities are multifaceted and shaped by migration to begin with; the idea that state territory is the private property of its existing citizens who can decide with whom to share this property raises questions of feudal-like property ownership (Carens 1987). To prevent jus domicile based citizenship from constituting an enshrined birth privilege and to uphold the liberal principle of universal human equality, 
entry into the territory of the political community must be open-otherwise, only persons born on community territory would possess the birth-right to jus domicile citizenship (Kostakopoulou 2008: 120) and the authority to select and exclude new members through immigration, and visa and residency restrictions.

Mobility constraints also constitute a social injustice (Hayter 2000). Mobility restrictions spatially lock workers into countries with low wage and labour standards where they are readily available for exploitation (Sassen 1988). Even classical and neo-classical economists agree that economies function most efficiently under conditions of complete labour mobility (Casey 2010). Yet, national immigration policies are typically designed to skim the international labour market for desired human capital and keep undesired labour out (Bauder 2003). Temporary foreign workers are admitted so that the national community can exploit their labour but do not have to extend the benefits, rights and entitlements associated with citizenship. Furthermore, restrictive border and migration politics produce a super-exploitable, criminalized underclass of non-status workers. Only the combination of open borders and jus domicile citizenship can address these contemporary practices of labour segmentation and exploitation at the practical level.

\section{Discussion}

The above discussion covered a large terrain. First, I highlighted that citizenship can function as a mechanism of distinction, domination and exploitation. Then, I suggested that the jus domicile principle of citizenship is capable of addressing the inequality and injustice associated with current citizenship practices. Finally, I argued for a combination of jus domicile citizenship and open borders. In particular, I proposed that free mobility would resolve contradictions between jus domicile and contemporary mobility and migration policies and prevent jus domicile from becoming a 'self-undermining' (Bosniak 2007: 398) citizenship practice. I reached these conclusions by considering liberal political philosophies of equality and social justice views emphasizing power relations. Although both perspectives are not always conceptually compatible, they have led me towards a common conclusion. While I recognize that it may be impossible to immediately implement the ideas presented in this article, given contemporary real-political circumstances (Casey 2010; Carens 2000; Kostakopoulou 2008), I believe these ideas are important for envisioning the possibility of an equitable and socially just future 'around which social action could converge and rotate' (Harvey 2011: 20).

In this final section, I highlight a few additional discussion points and contradictions that situate this article in a wider social, political and economic context. First, the principle of jus domicile holds on to citizenship as a territorial 
concept (Bosniak 2007). In this sense, the jus domicile principle of citizenship neither abolishes borders nor does it challenge political territoriality. Rather, this article envisions a world with permeable borders that geographically define political entities and citizenship. A continuing discussion of the merits of territorial vis-à-vis a-territorial concepts of citizenship could productively link questions of human mobility and the spatiality of political organization.

Second, the recognition that jus domicile is a territorial citizenship principle raises the question at which geographical scale this citizenship principle should be enacted. According to the dominant contemporary political paradigm, citizenship is implemented at the national scale. However, it is equally conceivable to rescale citizenship to the local, regional or supra-national scales. The European Union (EU) presents an interesting case in this respect. Although Italian nationals living in, say, Germany may not possess identical rights to German nationals, their EU citizenship grants them political rights, including the right to vote in municipal and EU elections, and mobility rights, including the right to stay or leave and return. This EU citizenship effectively enacts the jus domicile principle, rendering Italian nationals in Germany less vulnerable and subject to domination than so-called third-county nationals without EU citizenship. The European case also exemplifies that jus domicile can be practiced at local scales, where non-nationals possess the right to vote in municipal elections (Raijman et al. 2008; Siemiatycki 2006). Yet, the EU citizenship that bestows domicile rights has created a new scale of domination and distinction between EU citizens and non-EU-citizens. The jus domicile principle must not be applied selectively.

Third, citizenship exists within complex configurations of social, political and economic practices. Although the jus domicile principle of citizenship would neither abolish other mechanisms of domination and distinction nor guarantee that all people remain above a certain decency threshold, it would remove one important source of subordination and exploitation.

\section{Acknowledgements}

I thank Patti Lenard, Christine Straehle, and anonymous reviewers for their comments and the Centre for International Policy Studies for the generous invitation to discuss this paper at the workshop on Justice in Migration at the University of Ottawa on 11 March, 2011.

\section{Notes}

1 The term is an oversimplification. Due to space limitations, I am unable to elaborate.

2 Although these are possibilities. For example, jus domicile may be important to ascribe at birth to prevent that people are born stateless (Kostakopoulou 2008: 120; Arendt 1985 [1948]: 267-302). 
3 Kostakopoulou (2008: 114) argues that a condition of jus domicile is 'the intention to reside in a country indefinitely', although this intention may change as a person's circumstances change. This argument raises the question why the intention to reside in a place indefinitely should be necessary for the jus domicile citizenship principle to apply, rather than the contribution a person makes and the commitment this person has to the community at the moment. Why should the temporary nature of this contribution and commitment infringe on the acquisition of political, social and economic rights associated with citizenship? Why should jus domicile citizenship only be acquired after a certain probationary period, during which residents remain unequal, lack rights and are exploitable (as Canada's Life-in Caregiver Program exemplifies)?

4 I'm presenting a theoretical perspective here. For recent pragmatic views of open borders, see Casey (2010) or Bloom (2009).

\section{References}

Arendt, H. 1985 [1948]. The Origins of Totalitarianism. Orlando, FL: Harvest Books.

Austin, C. and Bauder, H. 2012. 'Jus Domicile: A Pathway to Citizenship for Temporary Foreign Workers?', in H. Bauder (ed.), Immigration and settlement: Challenges, Experiences, and Opportunities. Toronto: Canadian Scholars' Press.

Balibar, É. 2000. 'What We Owe to the San-Papiers', in L. Guenther and C. Heesters (eds), Social Insecurity, Alphabet City Series, no. 7. Toronto: Anansi.

Bauböck, R. 1994. Transnational Citizenship: Membership and Rights in International Migration. Aldershot: E. Elgar.

Bauder, H. 2003. 'Equality, Justice and the Problem of the International Border: A View from Canada', ACME 2(2): 167-82.

Bauder, H. 2006. Labor Movement: How Migration Regulates Labor Markets. New York: Oxford University Press.

Bauder, H. 2008. 'Citizenship as Capital: The Distinction of Migrant Labour', Alternatives: Global, Local, Political 33: 315-33.

Bloom, T. 2009. 'Just Open Borders? Examining Joseph Carens' Open Borders Argument in Light of a Case Study of Recent Somali Migrants to the UK', Journal of Global Ethics 5(3): 231-43.

Bosniak, L. 2007. 'Being Here: Ethical Territoriality Rights of Immigrants', Theoretical Inquiries in Law 8(2): 389-410.

Bourdieu, P. 1984. Distinction: A Social Critique of the Judgement of Taste. Cambridge, MA: Harvard University Press.

Bourdieu, P. 1986. 'The Forms of Capital', in J. G. Richardson (ed.), Handbook of Theory and Research for the Sociology of Education. New York: Greenwood Press.

Bourdieu, P. 2002. 'Against the Policy of Depoliticization', Studies in Political Economy 69: 31-41. 
Brown, C. 1992. 'Marxism and the Transnational Migration of People: Ethnical Issues', in B. Barry and R. E. Goodin (eds), Free Movement: Ethical Issues in the Transnational Migration of People and of Money. New York: Harvester Wheatsheaf.

Brubaker, R. 1992. Citizenship and Nationhood in France and Germany. Cambridge, MA: Harvard University Press.

Carens, J. H. 1987. 'Aliens and Citizens: The Case for Open Borders', Review of Politics 49: 251-73.

Carens, J. H. 2000. 'Open Borders and Liberal Limits: A Response to Isbister', International Migration Review 34(2): 636-43.

Carens, J. H. 2010. Immigrants and the Right to Stay. Cambridge, MA: MIT Press.

Casey, J. P. 2010. 'Open Borders: Absurd Chimera or Inevitable Future Policy?', International Migration 48(5): 14-62.

Cole, P. 2000. Philosophies of Exclusion: Liberal Political Theory and Immigration. Edinburgh: Edinburgh University Press.

Harvey, D. 2010. 'Roepke Lecture in Economic Geography: Crises, Geographic Disruptions and the Uneven Development of Political Responses', Economic Geography 87(1): 1-22.

Hayter, T. 2000. Open Borders: The Case Against Immigration Controls. London, Pluto.

Isin, E. and Turner, B. S. (eds). 2002. Handbook of Citizenship Studies. London: Sage.

Juss, S. S. 2004. 'Free Movement and the World Order', International Journal of Refugee Law 16(3): 289-335.

Kostakopoulou, D. 2008. The Future Governance of Citizenship. Cambridge: Cambridge University Press.

Raijman, R., Davidov, E., Schmidt, P. and Hochman, O. 2008. 'What Does a Nation Owe Non-Citizens? National Attachments, Perception of Perspective Threat and Attitudes towards Granting Citizenship Rights in a Comparative', International Journal of Comparative Sociology 49: 195-220.

Samers, M. 2010. Migration. Abingdon: Routledge.

Sassen, S. 1988. The Mobility of Labor and Capital: A Study in International Investment and Labor Flows. Cambridge: Cambridge University Press.

Sharma, N. 2006. Home Economics: Nationalism and the Making of 'Migrant Workers' in Canada. Toronto: University of Toronto Press.

Siemiatycki, M. 2006. The Municipal Franchise and Social Inclusion in Toronto: Policy and Practice. Toronto: Inclusive Cities Canada, Community Social Planning Council of Toronto (CSPC).

Soysal, Y. N. 1994. Limits of Citizenship: Migrants and Postnational Membership in Europe. Chicago: University of Chicago Press.

van Parijs, P. 1992. 'Citizenship Exploitation, Unequal Exchange and the Breakdown of Popular Sovereignty', in B. Barry and R. E. Goodin (eds), Free 
Movement: Ethnical Issues in the Transnational Migration of People and of Money. New York: Harvester Wheatsheaf.

Van den Anker, C. 2010. 'Introduction-Global Justice and Migration: A Multidisciplinary Conversation', Journal of International Political Theory 6(1): 47-50.

Verlinden, A. 2010. 'Free Movement? On the Liberal Impasse in Coping with the Immigration Dilemma', Journal of International Political Theory 6(1): 51-72.

Walters, W. 2006. 'Border/Control', European Journal of Social Theory 9(2): 187-203.

Walzer, M. 1983. Spheres of Justice: A Defense of Pluralism and Equality. Oxford: Martin Robertson. 